\title{
Multilevel spatial impact analysis of high-speed rail and station placement: A short-term empirical study of the Taiwan HSR
}

\author{
Yu-Hsin Tsai \\ National Chengchi University \\ yhsin@nccu.edu.tw \\ Yi-hsin Chung \\ Dept. of Urban Development, Taipei City \\ Government \\ panda1136530@gmail.com.tw
}

\author{
Jhong-yun Guan \\ Dept. of Urban Development, Taipei City \\ Government \\ kankuromomo@gmail.com
}

\begin{abstract}
Understanding the impact of high-speed rail (HSR) services on spatial distributions of population and employment is important for planning and policy concerning HSR station location as well as a wide range of complementary spatial, transportation, and urban planning initiatives. Previous research, however, has yielded mixed results into the extent of this impact and a number of influential factors rarely have been controlled for during assessment. This study aims to address this gap by controlling for socioeconomic and transportation characteristics in evaluating the spatial impacts of HSR (including station placement) at multiple spatial levels to assess overall impact across metropolitan areas. The Taiwan HSR is used for this empirical study. Research methods include descriptive statistics, multilevel analysis, and multiple regression analysis. Findings conclude that HSR-based towns, on average, may experience growing population and employment, but HSR-based counties are likely to experience relatively less growth of employment in the tertiary sector. HSR stations located in urban or suburban settings may have a more significant spatial impact. This differential in spatial change may be attributed to a high concentration of some subsectors and transportation services in the study area. Policy implications include adopting policies that encourage higher density at the local level, considering rural areas as a last choice for the installation of new HSR stations, and the use of HSR station placement to initiate brownfield urban regeneration in the urban core.
\end{abstract}

Keywords: High-speed rail, station placement, spatial distribution, multilevel analysis

\section{Article history:}

Received: September 15, 2019

Received in revised form: May

14, 2020

Accepted: May 26, 2020

Available online: November 4, 2020

Copyright 2020 Yu-Hsin Tsai, Jhong-yun Guan \& Yi-hsin Chung http://dx.doi.org/10.5198/jtlu.2020.1667

ISSN: $1938-7849$ | Licensed under the Creative Commons Attribution - Noncommercial License 4.0

The Journal of Transport and Land Use is the official journal of the World Society for Transport and Land Use (WSTLUR) and is published and sponsored by the University of Minnesota Center for Transportation Studies. 


\section{Introduction}

The impact of high-speed rail (HSR) services and station location on the spatial distribution of population and employment has implications for a wide range of planning decisions including cost-benefit analyses, the location selection process, and other complementary spatial and transportation initiatives such as urban regeneration (Bertolini, 1996) and feeder transit services (Murakami \& Cervero, 2012). Knowledge of potential impact is also used to guide real estate and other investments. Past research has contributed significantly to understanding how HSR improves middle-range inter-city accessibility (Willigers \& van Wee, 2011) and activities (Garmendia, Ureña, \& Coronado, 2011; Wu, Liang, \& Wu, 2016; Wetwitoo \& Kato, 2017), and how HSR initiates long-term growth in employment and population (Willigers \& van Wee, 2011) within major or secondary cities (Preston \& Wall, 2008; Li, Huang, $\mathrm{Li}, \&$ Zhang, 2016). Areas located within the HSR service-shed tend to experience more growth than those outside such sheds (Yin, Bertolini, \& Duan, 2015; Diao, 2018). Despite the highly targeted nature of these studies they have nonetheless greatly advanced our knowledge of HSR's spatial impact and together form the foundation for a more comprehensive and complex understanding.

The full extent of this impact and the ways in which relevant variables interact across spatial scales is where significant gaps in the literature remain. It is unclear whether HSR services contribute more significantly to the growth of large metropolitan centers, or inversely to a decentralization effect towards smaller cities (Chen, Loukaitou-Sideris, Ureña, \& Vickerman, 2019). Research has largely focused on the spatial impacts of HSR station placement on station-adjacent areas (Facchinetti-Mannone, 2009; Kim, Sultana, \& Weber, 2018), while less has been written on the metropolitan area itself as a whole. Crucial factors such as the existing socioeconomic and transportation characteristics of impacted areas in question remain to be taken into account when analyzing at various discrete levels (Ureña, Menerault, \& Garmendia, 2009) or across metropolitan areas (Chen et al., 2019). This empirical study, prompted by the 2007 opening of the Taiwan HSR (THSR) and the 2011 quinquennial National Industry and Commerce Survey (Taiwan Government, 2015a), addresses this relative lack of study on complex, multi-scalar spatial impact. The aims of the study are threefold: (1) to further the knowledge of HSR station placement impact across spatial levels, (2) to introduce methodological controls for socioeconomic and transportation characteristics when conducting multi-level analysis, and (3) to expand the usual scope of study by evaluating overall impact across multiple metropolitan areas. The first section reviews the literature on HSR's spatial effects on population and employment, the second describes the chosen research methods, the third looks at Taiwan's context and four THSR regression models based on multilevel analysis, and the final two sections discuss empirical results and potential policy implications drawn from this analysis.

\section{$2 \quad$ HSR's spatial impacts on population and employment}

Spatial redistribution of population and employment occurs for a variety of reasons driven by direct and indirect factors. In theory the relocation of households and firms can be triggered by HSR-reshaped territorial accessibility and resultant change in competitiveness between areas. In addition to individual patrons and firms whose business trips, primarily those of high value requiring face-to-face contact (Rouwendal \& Rietveld, 1994; Bruinsma \& Rietveld, 1998; Zheng \& Kahnb, 2013), require HSR (Willigers \& van Wee, 2011), HSR-driven relocation closer to a particular station or city usually involves a second, indirectly affected group. This group may include firms moving into HSR-driven communities driven by economic agglomeration to better provide local services as well as new residents moving for reasons such as shorter commute or better environment (Blum, Haynes, \& Karlsson, 1997; 
Kim, 2000). The previous literature discussing these multiple modalities of spatial redistribution can be organized according to the spatial level in question:

(1) Sub-city-level impacts. The mixed empirical findings on the significance of HSR's spatial impact at the sub-city-level (Hall, 2009; Chen et al., 2019) can be better interpreted with the assistance of HSR trip origin and destination patterns as well as an understanding of HSR's synergistic impacts when combined with other factors (Yin et al., 2015). Individual industries such as high-tech, information exchange (Freeman, 2007), leisure services, and conference industries are the most likely to relocate closer to HSR stations (Givoni, 2006; Hall, 2009). As far as patterns of population or industries as a whole are concerned, an HSR's impact zone is presumably associated with either the origin or destination of the associated HSR trips. These trips are reasonably further than walking distance while still occurring within a certain level of accessibility to the HSR station;, e.g., between 2 and 6 kilometers (Murakami \& Cervero, 2012; Shen, Silva, \& Martínez, 2014). In Taiwan's case some $60 \%$ of HSR trips which were produced or attracted to within a 10 kilometer radius for all eight stations across the country (Wang, Tsai, Chung, \& Guan, 2020).

In addition to this local impact catchment some research has argued that spatial differentials between areas equally affected by HSR may be attributed to other attractive characteristics that affect the relocating decisions of households and firms (Willigers \& van Wee, 2011). These attractive characteristics may include socioeconomic factors (urban hierarchy, economic structure, leisure facilities, and science parks), other transportation services (for example, feeder services and airports), planning interventions, availability of affordable land (Mohino, Loukaitou-Sideris, \& Ureña, 2014), and station placement itself (Chen et al., 2019).

(2) City-level impacts. It has been argued that HSR can improve inter-city cohesion (Garmendia, Ureńa, Ribalaygua, Leal, \& Coronada, 2008) and drive economic agglomeration either within major cities (Levinson, 2010; Preston \& Wall, 2008) or towards intermediate and secondary cities (Li et al., 2016; Diao, 2018) at the expense of smaller ones and the hinterland (Gutiérrez, González, \& Gomez, 1996; Ureña et al., 2009). Past literature partially supports the agglomeration within larger cities thesis, but studies have been inconclusive in cases of smaller or intermediate cities (Garmendia et al., 2008). Some (but not all) HSR-based cities closer to their metropolitan centres have been strengthened (Ureña et al., 2009; Mohino, Delaplace, \& Ureña, 2019) such as the London metro area (Chen \& Hall, 2011), but the more distant the city the less evident the impact (Chen et al., 2019). This inconsistent and complex impact on these peripheral cities may be attributable to their aforementioned attractive characteristics (Chen et al., 2019) and the life cycle that the metropolitan area itself is experiencing. Furthermore, in comparison to cities or regions outside of the HSR service-shed, those within the shed have more potential for attracting employment and stimulating population growth (Plassard, 1991, as cited by Willigers \& van Wee, 2011). However, it is empirically challenging to delineate the service-shed due to connecting transportation.

(3) Station location impact. HSR station location is classified as either urban core, suburbs, or rural area (Garmendia, Ureńna, \& Coronada, 2009; Hall, 2009). A range of factors may affect the selection of an HSR location including political conflicts and compromise (Norman \& Vickerman, 1999), ease and cost of land acquisition, accessibility to existing developed areas (Repolho, Antunes, \& Church, 2012; Troin, 1995, as cited by Garmendia et al., 2009), and a desire for new hinterland development. Different location alternatives may result in different land-use impacts (Bellet, 2009; Kim et al., 2018), and the more boardings and alightings that occur at a particular station the more potential that station holds for affecting land use. These impacts are better understood when one takes into account the endogeneity question regarding the non-random HSR station placement; whether the area's growth has attracted HSR, or HSR has attracted growth (Diao, 2018). Some research argues that stations located near the urban core are more likely to be successful (Facchinetti-Mannone, 2006, as cited by 
Chen \& Silva, 2014; Ureña et al., 2009; Zhao \& Chen, 2015), and those in rural areas unsuccessful (Facchinetti-Mannone, 2009). The urban core, however, is often the most expensive land available for further development. More evidence to elucidate station placement impact remains sparse, especially on metropolitan area level.

Several complicating factors call for more investigation to better understand HSR's spatial impacts at each of these respective levels and, more dynamically, across them. This includes the incorporation of socioeconomic and transportation characteristics across levels (Ureña et al., 2009) and the explicit inclusion of station placement in future analyses. The challenges associated with this type of work are formidable as HSR's spatial impacts are argued to materialize in the long term and include a sizeable spatial range, resulting in ever more factors to account for and compounding the complexity of the spatial change. Hence, descriptive statistics (Murakami \& Cervero, 2012) and mapping will not be comprehensive enough. Other challenges to future work include objectively defining structures such as intermediate cities, city tier organization, and HSR catchment zones.

\section{$3 \quad$ Methods}

The geographic scope of this research comprises the length of Taiwan; an island country boasting one of the densest populations worldwide and a 349.5-km-long, corridor-shaped THSR connecting most of the large urban areas along the western plain (Figure 1). With its current twelve stations total (4 stations having been added post-2015) THSR's average station-to-station distance is only 32 kilometers, one of the shortest worldwide and similar in structure to Japan's Morioka-Tokyo-Fukuoka line. The short, corridor-shaped line, short station-to-station distance, and high-density urban settings serve collectively to make THSR a unique case. The primary evaluation period for this study is the 5-year period beginning in 2006 one year before operation and ending in 2011, given the most recently available 2011 quinquennial National Industry and Commerce Survey (Taiwan Government, 2015a). All 8 pre-2015 stations spread across multiple city regions are incorporated in this study to provide a wider variety of HSR station placement, urban structure, and socioeconomic and transportation characteristics, as well as a more generalized impact assessment of HSR. The research methods utilized include descriptive statistics and spatial analysis to provide a preliminary assessment of the spatial impacts of HSR, as well as multilevel analysis and multiple regression analysis to further control for other explanatory factors. 


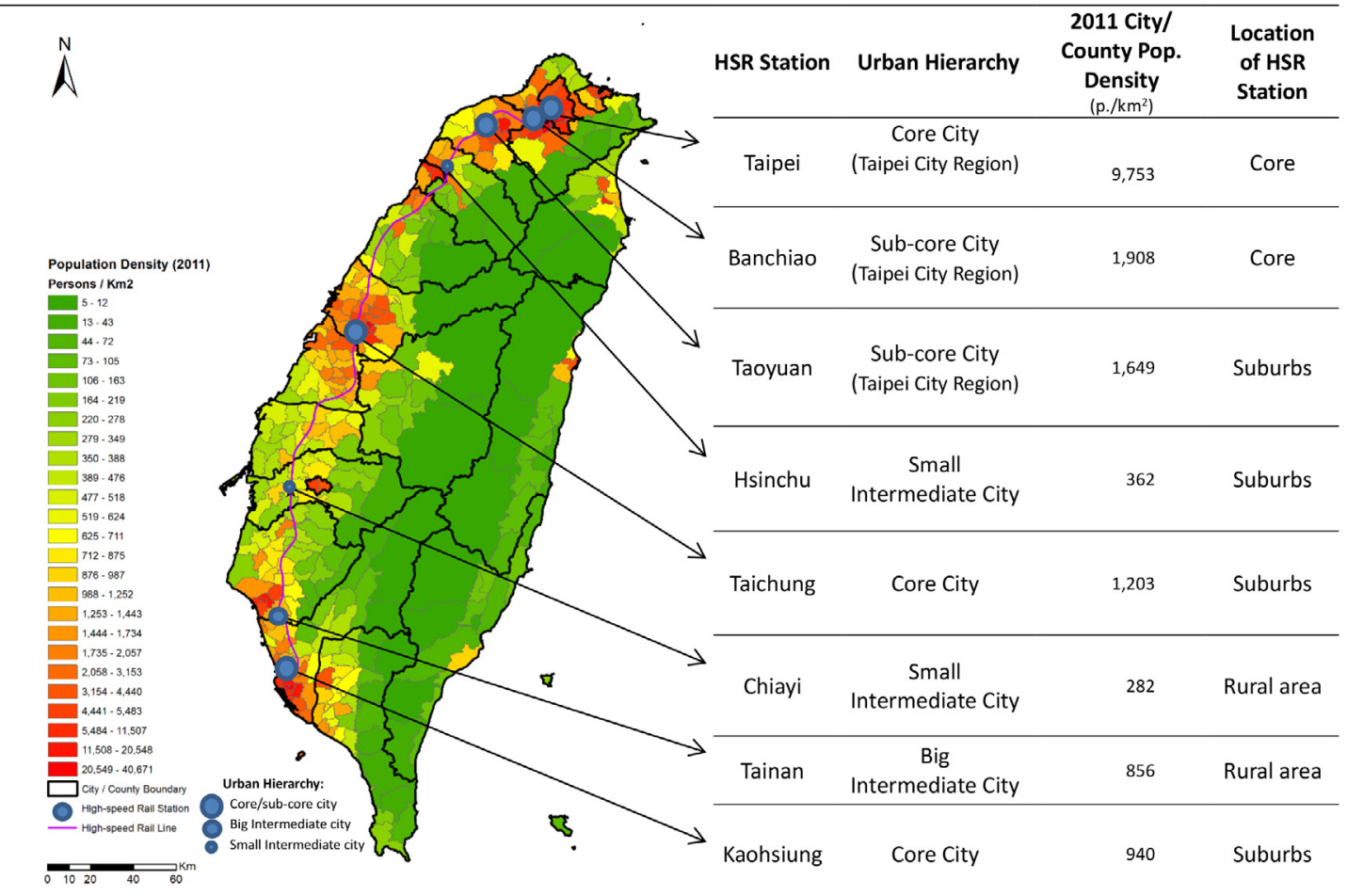

Source: Taiwan Government, 2015b

Figure 1. Taiwan HSR: Urban hierarchy, population density, and station location, 2011

\section{$4 \quad$ Taiwan's HSR and population and employment change}

The main island of Taiwan consists of 19 counties or cities (county from here on), and 352 towns or districts (town from here on). Most of Taiwan's population of approximately 23 million lived in 3 major city regions - Taipei (37\%, consisting of one core and 2 sub-core HSR-based cities), Taichung (12\%), and Kaohsiung (11\%) - as well as some intermediary cities (Tainan, Chiayi, and Hsinchu) (Taiwan Government, 2015b). The population totals ranged from 800,000 to 4 million (Table 1) and the population densities as of 2011 range from 280 to 9,750 persons $/ \mathrm{km}^{2}$ (Figure 1). Employment was distributed quite similarly to the population across the island. The average daily ridership for THSR was about 114,000 in 2011 . The average daily HSR ridership of each station in 2011 was generally positively associated with their population and employment while remaining concentrated in the 3 largest core cities, namely Taipei (29\%), Taichung (18\%), and Kaohsiung (17\%). Overall growth rate of HSR ridership between 2007 and 2011 was 124\%, with the fastest-growing counties located in northern and central Taiwan led by the two industrial cities Hsinchu and Taoyuan. 
Table 1. Population, employment and HSR ridership of Taiwan HSR-based counties or cities

\begin{tabular}{|c|c|c|c|c|c|c|c|c|c|c|}
\hline \multirow[t]{3}{*}{ HSR Station } & \multirow{3}{*}{$\begin{array}{c}\text { Urban } \\
\text { Hierarchy }\end{array}$} & \multirow{2}{*}{\multicolumn{2}{|c|}{ Population, $2011^{1}$}} & \multirow{2}{*}{\multicolumn{2}{|c|}{$\begin{array}{c}\text { Employment, } \\
2011^{5}\end{array}$}} & \multicolumn{5}{|c|}{ Average Daily HSR Ridership } \\
\hline & & & & & & \multicolumn{2}{|c|}{$2007^{6}$} & \multicolumn{2}{|c|}{$2011^{6}$} & \multirow{2}{*}{$\begin{array}{r}\text { '07-'11 } \\
\% \\
\end{array}$} \\
\hline & & Number & $\%$ & Number & $\%$ & Number & $\%$ & Number & $\%$ & \\
\hline Taipei & $\begin{array}{l}\text { Core City } \\
\text { (Taipei city } \\
\text { region) } \\
\end{array}$ & $2,650,968$ & $12 \%$ & $1,708,138$ & $21 \%$ & 13,241 & $26 \%$ & 33,563 & $29 \%$ & $153 \%$ \\
\hline Banchiao & $\begin{array}{c}\text { Sub-core City } \\
\text { (Taipei city } \\
\text { region) }\end{array}$ & $3,916,451^{2}$ & $17 \%$ & $1,193,287$ & $15 \%$ & 5,097 & $10 \%$ & 7,577 & $7 \%$ & $49 \%$ \\
\hline Taoyuan & $\begin{array}{c}\text { Sub-core City } \\
\text { (Taipei city } \\
\text { region) }\end{array}$ & $2,013,305$ & $9 \%$ & 828,228 & $10 \%$ & 3,205 & $6 \%$ & 9,544 & $8 \%$ & $198 \%$ \\
\hline $\begin{array}{c}\text { Sub-total } \\
\text { (Major part } \\
\text { of Taipei city } \\
\text { region) }\end{array}$ & - & $8,580,724$ & $37 \%$ & $3,729,653$ & $47 \%$ & 24,543 & $42 \%$ & 50,684 & $44 \%$ & $135 \%$ \\
\hline Hsinchu & $\begin{array}{l}\text { Small Inter- } \\
\text { mediate City }\end{array}$ & $937,693^{3}$ & $4 \%$ & 446,756 & $6 \%$ & 3,202 & $6 \%$ & 10,212 & $9 \%$ & $219 \%$ \\
\hline Taichung & Core City & $2,664,394$ & $12 \%$ & $1,007,705$ & $13 \%$ & 8,734 & $17 \%$ & 20,515 & $18 \%$ & $135 \%$ \\
\hline Chiayi & $\begin{array}{l}\text { Small Inter- } \\
\text { mediate City }\end{array}$ & $809,468^{4}$ & $4 \%$ & 169,419 & $2 \%$ & 2,882 & $6 \%$ & 5,612 & $5 \%$ & $95 \%$ \\
\hline Tainan & $\begin{array}{l}\text { Big Interme- } \\
\text { diate City }\end{array}$ & $1,876,960$ & $8 \%$ & 604,458 & $8 \%$ & 4,061 & $8 \%$ & 7,886 & $7 \%$ & $94 \%$ \\
\hline Kaohsiung & Core City & $2,774,470$ & $12 \%$ & 874,939 & $11 \%$ & 10,580 & $21 \%$ & 19,145 & $17 \%$ & $81 \%$ \\
\hline $\begin{array}{c}\text { Total } \\
\text { (HSR-based } \\
\text { Counties or } \\
\text { Cities) }\end{array}$ & - & $17,643,709$ & $77 \%$ & $6,832,930$ & $85 \%$ & 51,002 & $100 \%$ & 114,053 & $100 \%$ & $124 \%$ \\
\hline Taiwan & - & $23,013,766$ & $100 \%$ & $8,000,797$ & $100 \%$ & - & - & - & - & -- \\
\hline
\end{tabular}

Notes:

1. Source: Taiwan Government, 2015b

2. The population of New Taipei City, where Banchiao station resides

3. The total population of Hsinchu City and Hsinchu County

4. The total population of Chiayi City and Chiayi County

5. Source: Taiwan Government, 2015a

6. Source: Taiwan Government, 2018

Figures 2 and 3 reveal preliminary information regarding the likely impacts of HSR. Impacts, however, that are presumably driven in part by a mix of other factors. These 2 figures show the annual net change of population and employment per squared kilometer (that is, density), respectively, for the 2006 to 2011 evaluation period. The net change is calculated by deducting the national change from a town's specific change to represent the change due to migration or redistributive effects alone (Cao, Liu, Wang, \& Li, 2013). Density is adopted for standardization. Most of the net growth in population and employment occurred in the vicinity of HSR stations, particularly in northern Taiwan, and the impact is obscure for the 2 HSR stations located in the rural area (that is, Chiyi and Tainan). Most of the declines 
in net population and employment occurred in rural areas and eastern Taiwan. It is, however, unreliable to draw definnitive conclusions from these 2 figures alone as general patterns are not evident and precise, and other potential factors such as economic structure may influence the data.

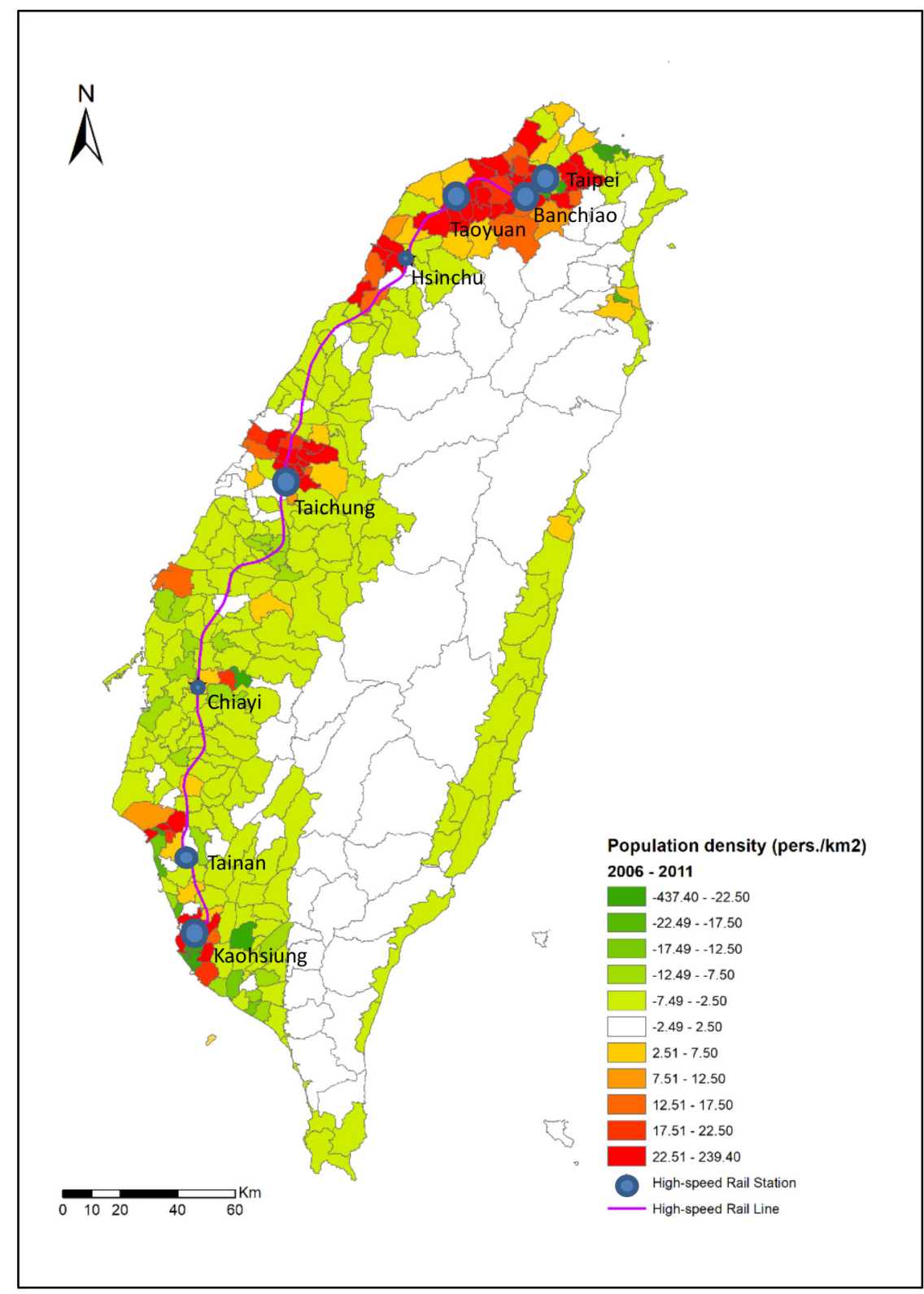

Source: Taiwan Government, 2015b

Note: Town's annual net change $=$ Town's annual change - National annual change

Figure 2. Annual net change of population density in Taiwan, town or district, 2006-2011 


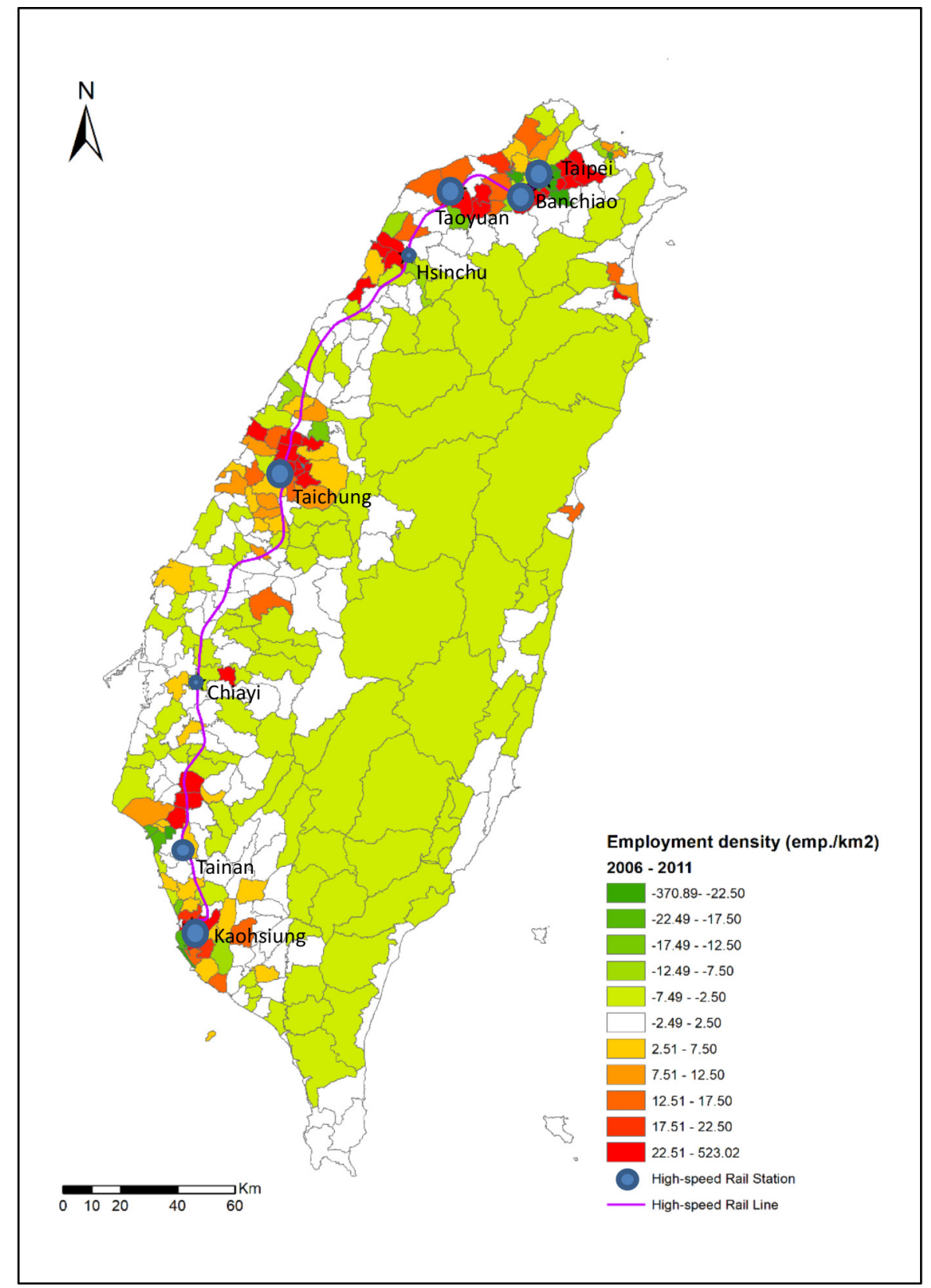

Source: Taiwan Government, 2015a

Figure 3. Annual net change of employment density by place of work in Taiwan, town or district, 2006-2011

Figure 4 presents additional descriptive statistics of annual net changes for the 8 THSR-based towns between 1991 and 2011 to supplement the limited information given in the maps above. This timeframe, broken down into four 5-year periods, was selected to cover significant THSR events namely the approval of the HSR plan (1990), the beginning of construction (1999), and the beginning of HSR operations (2007) - in order to further explore potential impacts across time. The results show, firstly, that most of the HSR-based towns experienced net population growth as early as immediately after THSR plan approval (6 out of 8), likely suggesting residents' anticipation of the service (Figure 4-1). All 8 of the HSR-based towns experienced net population growth after the HSR inauguration. The 
two towns with an HSR station located in the urban core are the only cases that experienced population growth less than the national average during these 20 years. In addition, no significant patterns were found for cities of a different urban hierarchy (that is, core, sub-core, and big and small intermediate cities) than where the HSR towns are located.

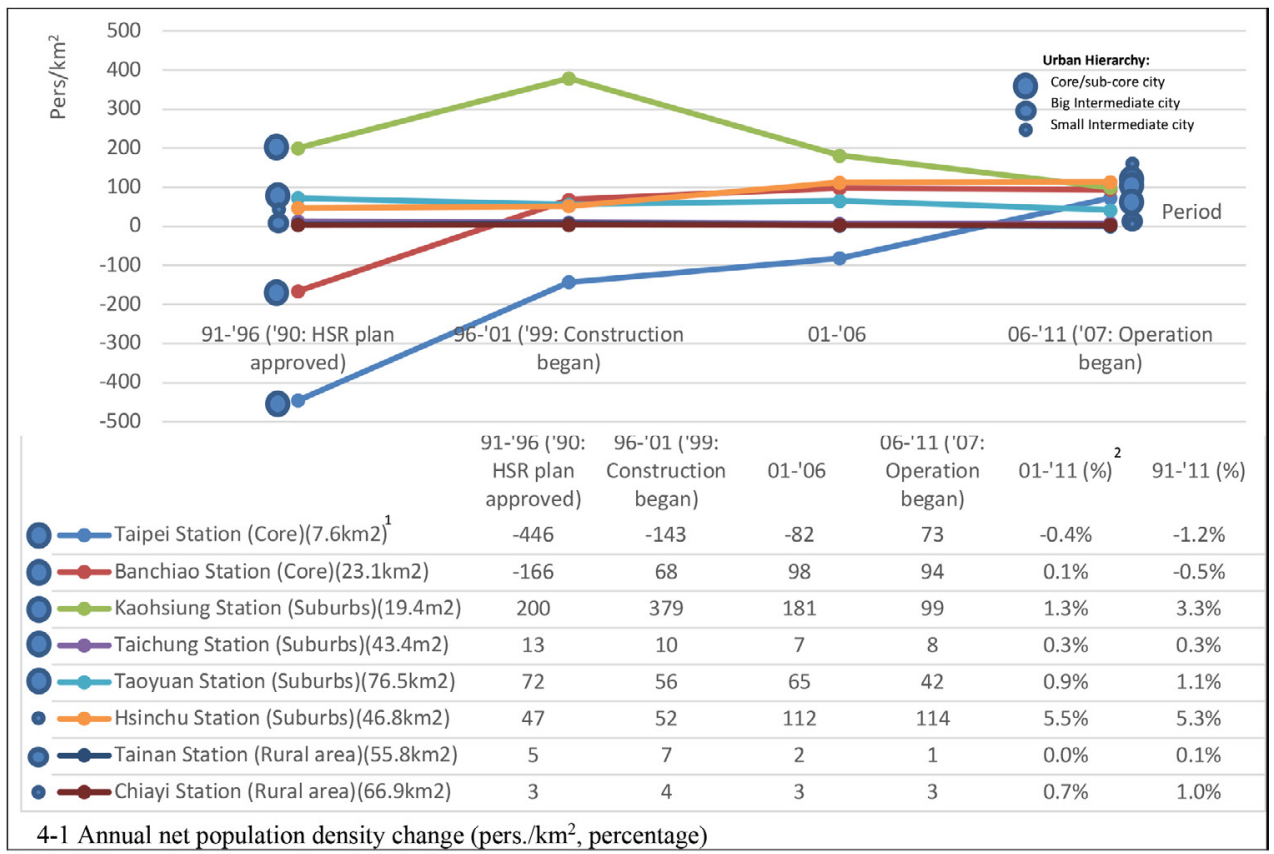

Notes:

1. The number in the parentheses is the land area

2. \% (i.e., Town's annual net percentage change) $=$ Town's annual percentage change - National annual percentage change

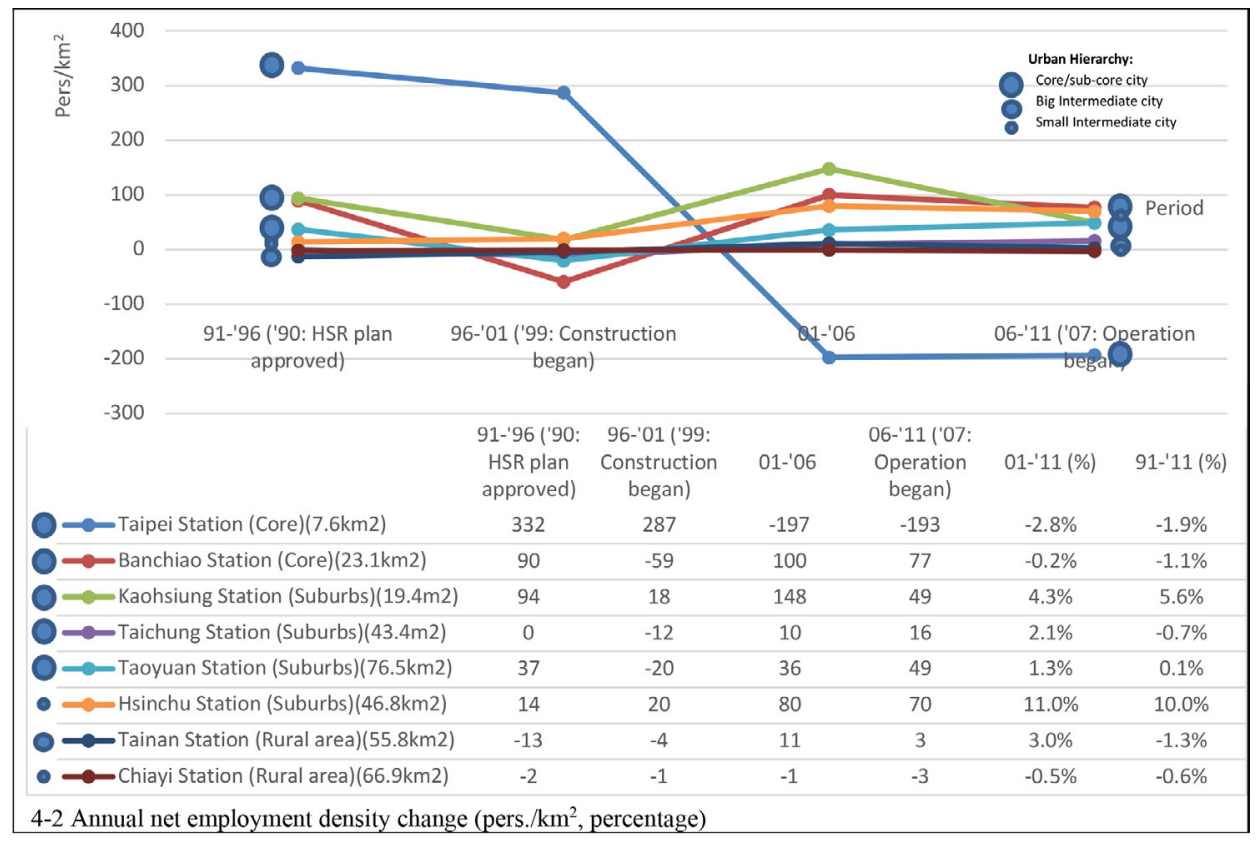

Figure 4. Annual net change of population and employment density of HSR-based towns: Post-HSR plan approval, postconstruction, and post-operations 
THSR's impacts on net employment in the secondary and tertiary sectors combined are similar to the above findings with respect to population change, save a few significant points: the highest increase in employment occurred later than the population increase (Figure 4-2), which may imply households are more responsive than employment in relocating due to HSR. Furthermore, the 2 rural HSR towns experienced minimal and even negative employment change (Chiayi) consistently during the 20 -year period. This may imply that their lowered accessibility to existing urbanized areas hindered potential economic development. These findings, however, are drawn from descriptive statistics and are still only preliminary in addressing HSR impact due to a lack of control for other influential variables. To resolve this issue the following section presents a multilevel analysis.

\section{$5 \quad$ Taiwan HSR multilevel modeling: Population and employment}

This study adopted multilevel modeling (also known as a hierarchical linear model or HLM) to develop four 2-level (that is, town and county) HLM models to assess the spatial impacts of THSR while controlling for other factors such as socioeconomic and transportation characteristics at multiple spatial scales (detailed below). HLM equips these models with the capacity to assess the impacts of HSR and other control variables at both county or town levels. In comparison with an ordinary least squares (OLS) regression method, HLM was selected firstly as it avoids the violation of the independence of observation assumption of OLS multiple regression (Paterson, 1991; Kreft \& Leeuw, 1998) due to the nested data of the research. ${ }^{i}$ An additional benefit of selecting HLM is that it provides extra information on variance across multiple levels via intraclass correlation coefficients (ICC) (Haynes, 1997). In the last two decades or so, HLM has become increasingly popular in the transportation and land use related fields to investigate the relationship between factors involving multiple spatial scales such as urban form, transportation (Ewing, 2005), travel behavior (Tsai, 2001), property values (Giuliano, Gordon, Pan, \& Park, 2010; Pan, 2019), and health (Ewing, Schmid, Killingsworth, Zlot, \& Raubenbush, 2003). These benefits aside, the results of the 4 HLM models are statistically the same as the OLS (detailed in the next section) and are regarded as generalizations of linear models (in particular, linear regression) in this study (Bryk \& Raudenbush, 2002). In short, HLM is a better method statistically and provides more information, but OLS is more easily comprehended and was therefore selected to present the results of the models.

The four 2-level HLM models are designed to evaluate THSR's impacts on land use regarding (1) residential use (the Population Model); (2) manufacturing-plus-services use (the Employment 2-3 Model); (3) manufacturing use (the Employment 2 Model); and (4) services use (the Employment 3 Model). Towns and counties are selected as 2 respective levels to assess THSR's impacts. In order to avoid "correlation does not imply causation" fallacies, the HLMs apply a before-and-after analysis framework for the 2006 to 2011 period to focus on the impact of HSR operations alone.i The annual net change in the densities of population and employment are adopted as the dependent variables (Tables 2 and 3). STATA and SPSS are the 2 primary software packages used to conduct HLM and multiple regression analysis, respectively. Before conducting HLM and multiple regression analyses, bivariate analysis is carried out to test the potential correlation for all dependent and independent variables. Curve fitting is also conducted to develop a possible functional form for the relationship between the dependent and independent variables. Collinearity is managed by avoiding the incorporation of highly correlated independent variables and by applying VIFs in the final models.

iTo illustrate this point: towns that are situated in the same county are clustered together because they share the same county characteristics and hence are not independent.

iiThe time periods before 2006 incorporated in the previous section are not adopted here in the HLMs primarily for two reasons: on the one hand, the change due to anticipation effects may not reflect the true impacts of HSR operation. On the other hand, justifying the anticipation effects during these periods requires controlling for all other influential factors, which is beyond the parameters of this research. 
Table 2. Taiwan HSR models: Annual net change of population and employment densities, 2006-2011

\begin{tabular}{|c|c|c|c|}
\hline \multicolumn{2}{|c|}{ Models } & \multicolumn{2}{|l|}{ Dependent Variable } \\
\hline \multicolumn{2}{|c|}{ (1) Population Model } & \multicolumn{2}{|l|}{ - Annual net population density change* (pers./km²) ('06-'11) } \\
\hline \multirow[t]{3}{*}{$\begin{array}{l}\text { Employment } \\
\text { Models }\end{array}$} & $\begin{array}{l}\text { (2) Emp. } 2+3 \\
\text { Model }\end{array}$ & \multicolumn{2}{|c|}{ - Annual net employment density change* (2nd+3rd sectors) (emp./km²) ('06-'11) } \\
\hline & (3) Emp. 2 Model & \multicolumn{2}{|c|}{ - Annual net employment density change* (2nd sector) (emp./km²) ('06-'11) } \\
\hline & (4) Emp. 3 Model & \multicolumn{2}{|c|}{ - Annual net employment density change* (3rd sector) (emp./km²) ('06-'11) } \\
\hline \multicolumn{2}{|c|}{ Characteristics } & Independent Variable & Causes of Impact \\
\hline \multicolumn{4}{|c|}{ Level One (Town/District) and Level Two (County/City) } \\
\hline \multirow[t]{2}{*}{ HSR Related } & HSR Services & $\begin{array}{l}\text { - HSR station }(0 / 1) \\
\text { - Euclidean distance }(\mathrm{ED}) \text { and networked dist. }(\mathrm{ND}) \text { to } \\
\text { closest HSR station }(\mathrm{km}) \\
\text { - HSR station w/n } 5 \mathrm{~km} \mathrm{ED}(0 / 1) \text { and ND }(0 / 1) \\
\left.\text { - HSR station density (stations } / \mathrm{km}^{2}\right) \\
\text { - HSR line length }(\mathrm{km}) \text {, density of HSR line length }(\mathrm{km} / \\
\left.\mathrm{km}^{2}\right) \\
\text { - } \# \text { of HSR trains per day }\end{array}$ & $\begin{array}{l}\text { HSR's elevation of inter-city accessi- } \\
\text { bility could trigger a concentration of } \\
\text { population or employment within a } \\
\text { certain distance from the given HSR } \\
\text { station (+). }\end{array}$ \\
\hline & $\begin{array}{l}\text { HSR Station } \\
\text { Location }\end{array}$ & $\begin{array}{l}\text { - Station in city core } \mathrm{w} / \mathrm{n} \text { administrative boundary }(0 / 1) \text {, } \\
\text { and } \mathrm{w} / \mathrm{n} 5 \mathrm{~km} \mathrm{ED}(0 / 1) \text { and ND }(0 / 1) \\
\text { - Station in the suburbs } \mathrm{w} / \mathrm{n} \text { administrative boundary } \\
(0 / 1) \text {, and w/n } 5 \mathrm{~km} \mathrm{ED}(0 / 1) \text { and } \mathrm{ND}(0 / 1) \\
\text { - Station in rural areas w/n administrative boundary }(0 / 1) \text {, } \\
\text { and } \mathrm{w} / \mathrm{n} 5 \mathrm{~km} \mathrm{ED}(0 / 1) \text { and ND }(0 / 1)\end{array}$ & $\begin{array}{l}\text { To locate HSR stations in the sub- } \\
\text { urbs versus urban core has the pros of } \\
\text { increased land availability and lower } \\
\text { rents (+), but also decreases acces- } \\
\text { sibility to population and employ- } \\
\text { ment (-). }\end{array}$ \\
\hline \multirow[t]{2}{*}{$\begin{array}{l}\text { Urban Hierarchy } \\
\text { and Economic } \\
\text { Size, and Eco- } \\
\text { nomic Structure }\end{array}$} & $\begin{array}{l}\text { Urban Hierarchy } \\
\text { and Economic } \\
\text { Size }\end{array}$ & $\begin{array}{l}\text { - Urban hierarchy (core, sub-core, big intermediate, small } \\
\text { intermediate, and others) }(0 / 1) \text {, population size, employ- } \\
\text { ment size ( } 2 \mathrm{nd}+3 \mathrm{rd} \text { sectors), quartile of population size } \\
\text { - Distance to closest county with a population of } 1 \text { mil- } \\
\text { lion or larger }(\mathrm{km}) \text {, with county with a population of } 1 \\
\text { million or larger within } 10 \mathrm{~km}(0 / 1) \\
\text { - Population density }\left(\mathrm{p} . / \mathrm{km}^{2}\right) \text {, employment density } \\
\text { - County/city }(0 / 1)\end{array}$ & $\begin{array}{l}\text { The largest city may reap the greatest } \\
\text { economic benefits at the expense of } \\
\text { other cities. }\end{array}$ \\
\hline & $\begin{array}{l}\text { Economic } \\
\text { Structure }\end{array}$ & $\begin{array}{l}\text { - Economic structure: Location quotient, coefficient of } \\
\text { localization }(\mathrm{COL})\left(2^{\text {nd }}+3^{\text {rd }} \text { sectors, and sub-sectors, e.g., }\right. \\
\text { pharmaceuticals \& chemical products manufacturing; } \\
\text { electronics, \& optical products manufacturing; travel } \\
\text { services) } \\
\text { - Science park }(0 / 1) \text {; \# of science parks; Density of science } \\
\left.\text { parks (parks } / \mathrm{km}^{2}\right) ; \# \text { of firms in science parks; Density of } \\
\left.\text { science park firms (firms } / \mathrm{km}^{2}\right) \\
\text { - Export-processing zone }(\mathrm{EPZ})(0 / 1) \text {; \# of EPZs; Density } \\
\text { of EPZs }\left(E P Z s / \mathrm{km}^{2}\right) ; \# \text { of firms in EPZs; Density of } \\
\left.\text { EPZ firms (firms } / \mathrm{km}^{2}\right)\end{array}$ & $\begin{array}{l}\text { The economic structure could affect } \\
\text { employment, such as through eco- } \\
\text { nomic agglomeration due to specific } \\
\text { prominent industries, and in turn } \\
\text { could result in increased residential } \\
\text { and service activities }(+) \text {. }\end{array}$ \\
\hline Transportation & $\begin{array}{l}\text { HSR Shuttle } \\
\text { Buses }\end{array}$ & $\begin{array}{l}\text { - HSR shuttle bus }(0 / 1) \\
\text { - \# of HSR shuttle bus routes; Density of HSR shuttle bus } \\
\text { routes (routes } / \mathrm{km}^{2} \text { ) } \\
\text { - \# of HSR shuttle bus stops; Density of HSR shuttle bus } \\
\text { stops (stops } / \mathrm{km}^{2} \text { ) }\end{array}$ & $\begin{array}{l}\text { Increased shuttle services could at- } \\
\text { tract HSR-related activities (+). }\end{array}$ \\
\hline
\end{tabular}




\begin{tabular}{|c|c|c|}
\hline Characteristics & Independent Variable & Causes of Impact \\
\hline \multicolumn{3}{|c|}{ Level One (Town/District) and Level Two (County/City) } \\
\hline $\begin{array}{l}\text { Mass Rapid } \\
\text { Transit }\end{array}$ & $\begin{array}{l}\text { - } \text { MRT }(0 / 1) \\
\text { - \# of MRT stations; Density of MRT stations (stations/ } \\
\left.\mathrm{km}^{2}\right) \\
\text { - Length of MRT lines }(\mathrm{km}) \text {; Density of MRT lines }(\mathrm{km} / \\
\left.\mathrm{km}^{2}\right)\end{array}$ & $\begin{array}{l}\text { MRT stations could attract residen- } \\
\text { tial activities or employment to the } \\
\text { stations' proximity (+), but could also } \\
\text { channel these results to alternative } \\
\text { locations when considering housing } \\
\text { size, rent prices or community qual- } \\
\text { ity (-). }\end{array}$ \\
\hline Rail & $\begin{array}{l}\text { - Rail }(0 / 1) \\
\left.\text { - \# of rail stations; Density of rail stations (stations } / \mathrm{km}^{2}\right) \\
\text { - Length of rail lines }(\mathrm{km}) \text {; Density of rail lines }\left(\mathrm{km} / \mathrm{km}^{2}\right)\end{array}$ & $\begin{array}{l}\text { Rail services could attract residential } \\
\text { activities or employment to nearby } \\
\text { rail stations }(+) \text {. }\end{array}$ \\
\hline Highway & $\begin{array}{l}\text { - Inter-city highway }(0 / 1) \\
\text { - Length of inter-city highway }(\mathrm{km}) \text {; Density of inter-city } \\
\text { highway }\left(\mathrm{km} / \mathrm{km}^{2}\right) \\
\text { - Highway interchange }(0 / 1) \text {; \# of highway interchange; } \\
\left.\text { Density of interchange (Interchanges } / \mathrm{km}^{2}\right)\end{array}$ & $\begin{array}{l}\text { Increased inter-city highway acces- } \\
\text { sibility could trigger a concentration } \\
\text { of population or employment within } \\
\text { a certain distance from highway } \\
\text { interchanges (+). }\end{array}$ \\
\hline
\end{tabular}

*Note: Town's annual net change $=$ Town's annual change - National annual change 
Table 3. Descriptive statistics of selected variables: Taiwan HSR models

\begin{tabular}{|c|c|c|c|}
\hline Variables & Mean/Mode & $S D$ & Range \\
\hline \multicolumn{4}{|l|}{ Dependent Variables (Town/District) } \\
\hline Annual net pop. density change (pers./ $\mathrm{km}^{2}$ ) ('06-'11) & .02 & 51.1 & $-437-239$ \\
\hline Annual net emp. density change ( $2 \mathrm{nd}+3 \mathrm{rd}$ sectors) $\left(\mathrm{emp} . / \mathrm{km}^{2}\right)\left({ }^{\prime} 06-11\right)$ & 2.1 & 86.1 & $-1,233-523$ \\
\hline Annual net emp. density change (2nd sector) (emp./km²) ('06-'11) & -.3 & 28.7 & $-291 \sim 153$ \\
\hline Annual net emp. density change (3rd sector) (emp./km²) ('06-'11) & 2.4 & 68.2 & $-1,022-474$ \\
\hline \multicolumn{4}{|l|}{ Independent Variables } \\
\hline \multicolumn{4}{|l|}{ Town/district Level Variables $(\mathrm{N}=349)$ : } \\
\hline \multicolumn{4}{|l|}{ HSR services: } \\
\hline HSR station $(0 / 1)$ & $0(2.4 \%)^{*}$ & .15 & $0 \sim 1$ \\
\hline ED to closest HSR station $(\mathrm{km})$ & 22.4 & 21.9 & $0 \sim 108$ \\
\hline HSR station density (stations $/ \mathrm{km}^{2}$ ) & $9.1 \mathrm{e}-4$ & $8.2 \mathrm{e}-3$ & $0 \sim .13$ \\
\hline HSR station w/n 5 km ED (0/1) & $0(21.0 \%)^{*}$ & .40 & $0 \sim 1$ \\
\hline HSR station w/n 5 km ND (0/1) & $0(4.3 \%)$ & .20 & $0 \sim 1$ \\
\hline \# of HSR trains per week & 769.5 & 194.5 & $518-954$ \\
\hline \multicolumn{4}{|l|}{ HSR station location: } \\
\hline Station in the city core, w/n $5 \mathrm{~km}$ ED (0/1) & $0(7.0 \%)^{*}$ & .25 & $0 \sim 1$ \\
\hline Station in the suburbs, w/n $5 \mathrm{~km} \mathrm{ED}$ & $0(10.4 \%)^{*}$ & .30 & $0 \sim 1$ \\
\hline Station in the rural area, w/n $5 \mathrm{~km}$ ED & $0(3.7 \%)^{*}$ & .18 & $0 \sim 1$ \\
\hline \multicolumn{4}{|l|}{ HSR shuttle buses: } \\
\hline HSR shuttle bus routes per $\mathrm{km}^{2}$ & .0004 & .019 & $0 \sim .18$ \\
\hline HSR shuttle bus stops per $\mathrm{km}^{2}$ & .015 & .080 & $0-.86$ \\
\hline \multicolumn{4}{|l|}{ Urban hierarchy, economic size, and economic structure } \\
\hline Emp. density (pers./km²) ('06) & 1,169 & 3,417 & $0.1 \sim 23,834$ \\
\hline $\begin{array}{l}\text { COL of computers, electronics, \& optical products manufacturing (emp.- } \\
\text { based) }\end{array}$ & .00 & .01 & $-.03 \sim .07$ \\
\hline $\begin{array}{l}\text { Location quotient (LQ) of travel \& related booking services (emp.-based) } \\
\text { ('06) }\end{array}$ & .23 & 1.21 & -18.7 \\
\hline \# of firms in science parks & 2.53 & 18.3 & $0 \sim 273$ \\
\hline \# of science park firms per $\mathrm{km}^{2}$ & .87 & 5.97 & $0 \sim 81.36$ \\
\hline $\operatorname{EPZ}(0 / 1)$ & $0(26.8 \%)^{*}$ & .45 & $0 \sim 1$ \\
\hline \multicolumn{4}{|l|}{ Transportation: } \\
\hline Mass rapid transit $(0 / 1)$ & $0(9.5 \%)^{*}$ & .30 & $0 \sim 1$ \\
\hline \# of mass rapid transit stations per $\mathrm{km}^{2}$ & .038 & .188 & $0-2.024$ \\
\hline$\#$ of mass rapid transit lines per $\mathrm{km}^{2}$ & .048 & .231 & $0-2.428$ \\
\hline \# of train stations per $\mathrm{km}^{2}$ & .019 & .071 & $0 \sim 1.136$ \\
\hline \# of highway interchanges per $\mathrm{km}^{2}$ & .009 & .010 & $0 \sim .052$ \\
\hline
\end{tabular}




\begin{tabular}{|c|c|c|c|c|c|}
\hline County/city Level Variables ( $\mathrm{N}=19)$ : & & & & & \\
\hline HSR services: & & & & & \\
\hline HSR station density (stations $/ \mathrm{km}^{2}$ ) & .013 & & .035 & & $0 \sim .15$ \\
\hline HSR station location: & & & & & \\
\hline Station in the city core w/n administrative boundary $(0 / 1)$ & $0(42.1 \%)^{*}$ & & .51 & & $0 \sim 1$ \\
\hline Closest station (network-based) in the city core $(0 / 1)$ & $0(21.1 \%)^{*}$ & .42 & & $0 \sim 1$ & \\
\hline Closest station (network-based) in the suburbs $(0 / 1)$ & $1(57.9 \%)^{*}$ & .51 & & $0 \sim 1$ & \\
\hline Urban hierarchy, economic size, \& economic structure & & & & & \\
\hline Density of science park firms (firms $/ \mathrm{km}^{2}$ ) & 12.0 & 19.2 & & $0 \sim 62.3$ & \\
\hline Density of EPZ firms (firms $/ \mathrm{km}^{2}$ ) & .015 & .05 & & $0 \sim .21$ & \\
\hline Transportation: & & & & & \\
\hline \# of mass rapid transit lines per $\mathrm{km}^{2}$ & .018 & .068 & & $0 \sim .30$ & \\
\hline \# of mass rapid transit stations per $\mathrm{km}^{2}$ & .016 & .064 & & $0 \sim .28$ & \\
\hline
\end{tabular}

Note: ${ }^{*}$ The number in the parentheses is the percentage.

Two-level random-intercept models are then selected for simplicity purposes. iiifollowing this, each town's observation is predicted (Equation 1) along with the predicted value of the county (that is, the county's growth) where the town is located (Equation 2-1) as the baseline, plus the town's variation due to its characteristics (Equation 1). The details of the two-level models are specified below:

\section{Level 1: Town}

Town's Growth ${ }_{\mathrm{ij}}=\alpha_{0 \mathrm{j}}$ (i.e., county's growth) +

$$
a_{1 j} X_{1 i j}+a_{2 j} X_{2 i j}+\ldots+\alpha_{p j} X_{p i j}+a_{e j * f f} X_{e i j} * X_{f i j}+\ldots+T_{i j}
$$

Where Town's Growth ${ }_{\mathrm{ij}}$ is the net population or employment growth of town $\mathrm{i}$ in county $\mathrm{j}$,

$\mathrm{i}=1, \ldots, \mathrm{i}$, denotes town $\mathrm{i}$ (Level 1 ),

$j=1, \ldots, j$, denotes county $j($ Level 2 ), and

$\mathrm{p}=1, \ldots, \mathrm{p}$, denotes town-level variable $\mathrm{p}$;

$\mathrm{X}_{\mathrm{pij}}$ is town-level variable $\mathrm{p}$ of town $\mathrm{i}$ in county $\mathrm{j}$;

$a_{\mathrm{oj}}$ represents the growth of county $\mathrm{j}$ (predicted from Equation 2-1);

$\alpha_{p j}$ denotes the regression coefficients of town-level variable p in county j (predicted from Equation 2-2);

$\alpha_{\mathrm{e}^{*} \mathrm{f} f}$ denotes the regression coefficient of the interaction between town-level variable e and variable $\mathrm{f}$ in county $\mathrm{j}$, and;

$\mathrm{T}_{\mathrm{ij}}$ denotes the model error of town $\mathrm{i}$ in county $\mathrm{j}$.

iii The random-intercept models, in which the coefficients of the town-level variables are the same across counties, is chosen for simplicity purposes, since these HLM models are already complicated to operate and comprehend. 


\section{Level 2: County}

$$
\begin{aligned}
& \left.\left.\alpha_{0 j} \text { (i.e., county's growth }\right)=\beta_{00} \text { (i.e., national growth }\right)+ \\
& \beta_{10} Y_{1 j}+\beta_{20} Y_{2 j}+\ldots+\beta_{q 0} Y_{q j}+U_{0 j} \\
& \left.\begin{array}{l}
a_{1 j}=\beta_{01}+U_{1 j} \\
a_{2 j}=\beta_{02}+U_{2 j}
\end{array}\right\} \\
& a_{p j}=\beta_{0 p}+U_{p j}
\end{aligned}
$$

Where $Y_{q j}$ denotes county-level variable $q$ of county $j, q=1, \ldots, q$;

$\beta_{00}$ represents national growth;

$\beta_{\mathrm{qo}}$ denotes the regression coefficient of county-level variable $\mathrm{q}$ for predicting county's growth;

$\beta_{0 \mathrm{p}}$ denotes the intercept for predicting the coefficient of town-level variable $\mathrm{p}$; and

$\mathrm{U}_{\mathrm{pj}}$ denotes the model error of the county growth or the regression coefficient of town-level variable p in county $j$.

Equation 2-1 predicts a county's growth magnitude with both the national growth magnitude and the county's characteristics. Equations 2-2 predicts the coefficients of town-level variables, where they are assumed to be fixed in the random-intercept models.

As the actual determinant relationships concerning HSR are presumably unknown, an array of varied forms of HSR variables have been created and tested regarding their statistical relationship with the dependent variables. Through this sensitivity testing process the variables with the highest statistically significant coefficients are selected. HSR variables include: (a) catchment-based type, such as availability within the administrative boundary (e.g., dummy variable for availability of HSR station) or a certain distance (e,g., 5 kilometers) (Murakami \& Cervero, 2012); (b) proximity-based type (e.g., Euclidean distance (ED) to the closest HSR station); and (c) the level-of-availability type (e.g., HSR stations per square kilometer), and level of service (for example, train frequency). Wherever possible both networked distance (ND) and ED measurements are applied. The locations of HSR stations are classified into three areas: the city core, suburbs, and rural areas. These classifications are based on the relative population density of the setting (Figure 1).

The HLMs incorporate an array of independent variables as control variables, including urban hierarchy and economic size (Pedro \& Silva, 2013), economic structure (Kasarda, 2009), and transportation-related variables (Table 2) to investigate the impacts of HSR more accurately and to explain why different towns and counties have different population and employment change patterns. These types of variables have been considered less often in past research. Urban hierarchy and economic size variables include urban hierarchy, population size, employment size, as well as the varied forms of these variables (e.g., the actual number and the quantile of population size). Please note that the justification for incorporating these various alternative variables is the same as above; their theoretical or quantitative relationships are presumably unclear and therefore the same sensitivity test has also been conducted. Economic structure variables include the town's and county's location quotient (LQ) and the coefficient 
of localization (COL) $)^{\text {iv }}$ for secondary and tertiary sectors. The approximately 20 sub-sectors $^{v}$ that may take advantage of HSR for business or commute hold industrial characteristics such as being knowledgeintensive, time-sensitive, high-value-added, and face-to-face communication assistive (Hall, 2009; Freeman, 2007). These economic structure variables include alternative forms for the availability of science parks and export-processing zones $\left(\mathrm{EPZ}^{\mathrm{vi}}\right)$ and are all subject to the same sensitivity testing.

The transportation variable of the free HSR shuttle buses that serve THSR passengers at mostly non-city-core HSR stations is adopted to control for impact. Transportation policies of mass rapid transit (MRT) systems (available at the three largest HSR stations in Taipei, Banchiao, and Kaohsiung), conventional rails connecting HSR's services to the cities (available at all HSR stations except for Taoyuan and Chiayi) or acting as inter-city transportation, and inter-city highway systems are quantified as well. Other transportation modes may reinforce or suppress HSR impacts depending upon whether they serve as a local supplementary feeder service to HSR or as an alternative inter-city competitor.

\section{Empirical results of Taiwan HSR multiple regression models: Population and employment}

Based on the county-level ICC values of the 4 models, all close to zero (as well as lower than the arguable 10 percent cutoff point (Diya, Li, Van den Heede, Sermeus, \& Lesaffre, 2014)) (Table 4), the OLS multiple regression analysis provides statistically equivalent results to the 2-level HLMs ${ }^{\text {vii }}$ (Woltman, Feldstain, MacKay, \& Rocchi, 2012). As the results from the OLSs are more easily understood they are selected to show the results of the models. Sample sizes at the town level for the 4 models are around 340 each. These models are all statically significant (Ps $=.0$ in F-tests), and all the incorporated variables are statistically significant (Ps $<=.05$ ) and not collinear (VIFs $<10)$. The R-squared values of the 4 models are $.51, .67, .55$, and .64 for the Population, Employment 2-3, Employment 2, and Employment 3 Models, respectively.

\footnotetext{
iv Both LQ and COL can measure the concentration of a given industry in an area when compared to the nation. LQ industry $\mathrm{A}=$ (Percentage of area's employment in industry A) / (Percentage of national employment in industry A); COL industry A = (Percentage of area's employment in industry A) - (Percentage of national employment in industry A) (Isard, 1960). The value of LQ of 1 and the value of COL of 0 both indicate exactly the same distribution of the given industry as the national distribution; the value of LQ greater than 1 and the value of COL greater than 0 both indicate higher concentration of the industry. v Based on the standard industrial classification system applied in the Taiwan Government's National Industry and Commerce Surveys (2015a), the sub-sectors incorporated include: (1) electronic parts and components manufacturing; (2) computers and electronic and optical products manufacturing; (3) electrical equipment manufacturing; (4) machinery and equipment manufacturing; (5) wholesale trade for household products; (6) wholesale trade for the manufacturing industry; (7) accommodation services; (8) food and beverage services; (9) financial services; (10) real estate services; (11) legal and accounting services; (12) business consulting services; (13) architecture and civil engineering services; (14) advertising and market research services; (15) professional, scientific and technical services; (16) design industry; (17) car rental services; (18) travel agency; (19) convention centers and trade shows services; (20) education; (21) health services; and (22) creative, arts and entertainment activities.

${ }^{\text {vi }} \mathrm{An} \mathrm{EPZ} \mathrm{is} \mathrm{a} \mathrm{specific} \mathrm{type} \mathrm{of} \mathrm{free-trade} \mathrm{zone} \mathrm{generally} \mathrm{set} \mathrm{up} \mathrm{by} \mathrm{governments} \mathrm{to} \mathrm{promote} \mathrm{industrial} \mathrm{and} \mathrm{commercial} \mathrm{exports}$ in developing countries.

vii The cutoff point and the use of HLM when the cutoff value is low is still inconclusive. The $10 \%$ cutoff point is still lack of consensus since it is based on arbitrary judgement (Nezlek, 2012). Others, however, argue that HLM needs to be used whenever the data structure involves a hierarchical nature regardless of the size of ICC values (Hayes, 2006).
} 


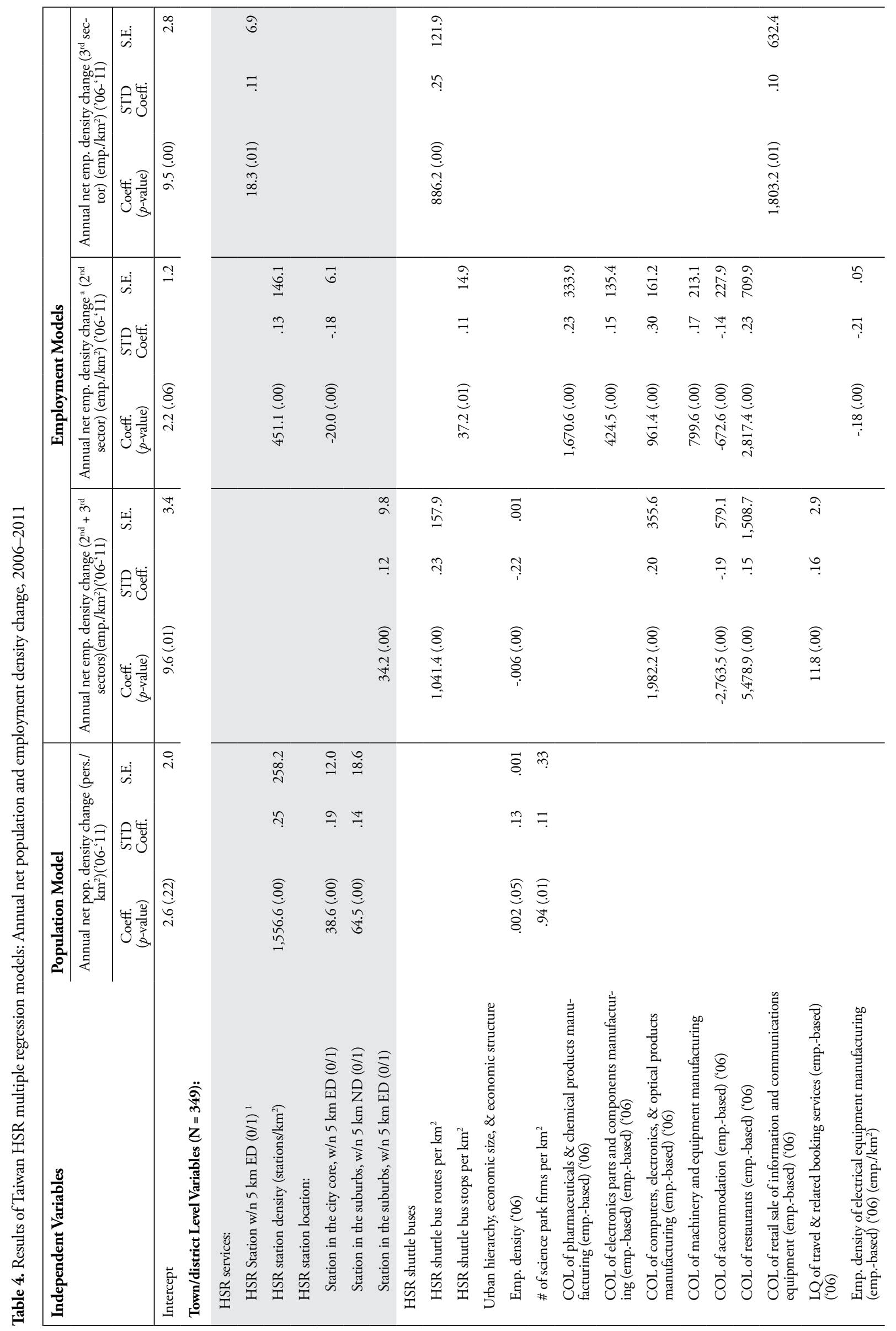




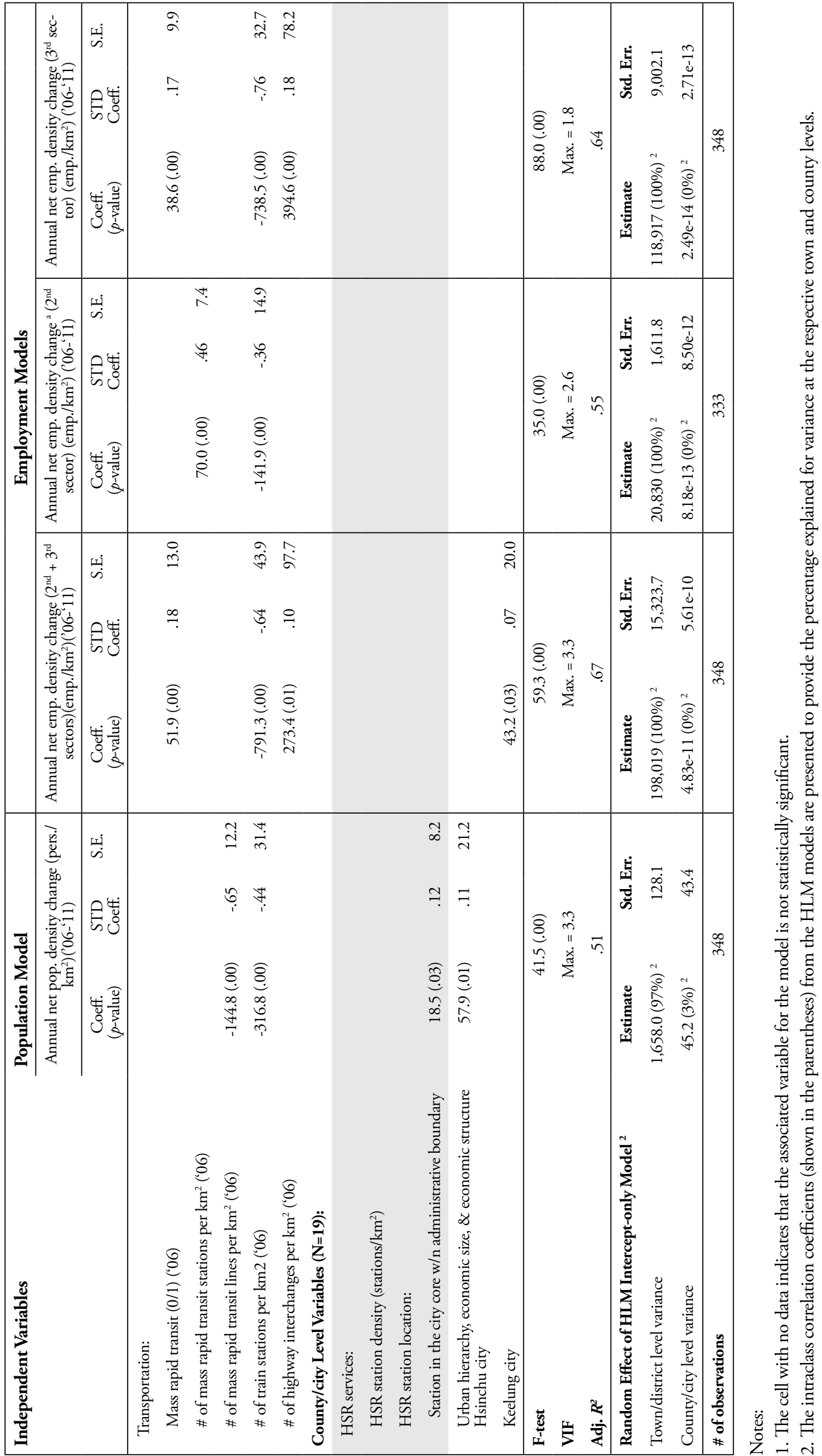


The significant impacts are illustrated by variable type as follows:

HSR's impacts on population change. Firstly, the Population Model reveals a statistically significant positive coefficient at town level of the HSR station density variable (Table 4), representing the reciprocal of HSR-serviced land area where an HSR station resides. This statistic implicitly indicates, ceteris paribus, that HSR towns on average attracted more population than others, though not necessarily within the direct vicinity of the station. Based on its standardized coefficient (SDC) of .25, a town having an HSR station during THSR's initial operation period was the third most crucial factor affecting its population migration. This influence was far behind that of MRT services $(\mathrm{SDC}=-.65)$ and train services $(\mathrm{SDC}=-.44)$, however, which may reflect that these various transportation modes or the areas where they resided were at different stages of development and, hence, had varied influence.

Secondly, the results support that when the station placement is taken into consideration for the average impact on the HSR towns, an HSR station in the city core or suburban area stimulated population migration to the town within a 5-kilometer radius. The coefficients of these stations located in the city core and suburbs indicate that, other factors being equal, the population on average annually increased by 38.6 and 64.5 persons per square kilometer, respectively. At the county level counties with HSR stations located around the city core experienced increased population immigration on an average of 18.5 persons per square kilometer.

HSR's impacts on employment change. Firstly, at the town level HSR's impact on a town's overall employment in the secondary and tertiary sectors combined was significant when the station was established in the suburbs, while at county level HSR was negatively correlated with the change of overall employment. The Employment 2-3 Model reveals that none of the HSR-related variables are statistically significant. When considering station placement suburban stations increased the overall employment of the town located in a 5-kilometer $(\mathrm{ED})$ radius of the HSR station to a higher degree $(\mathrm{SDC}=.12)$ than elsewhere. Nonetheless, this factor was one of the least crucial.

At the county level, however, the negative coefficient of HSR station density (SDC $=-.12$ ) suggests that the growth of overall employment in the tertiary and secondary sectors of HSR counties was less than the national average. This evidence does not support the anticipated finding that HSR would boost economic development on a larger, countywide scale. One possible explanation could be that nearby non-HSR counties also take advantage of HSR by using other inter-city transportation that connects HSR stations (Wu et al., 2016; Wetwitoo \& Kato, 2017). This phenomenon also occurred in the Employment 3 Model $(\mathrm{SDC}=-.24)$, indicating that employment in the non-HSR counties' tertiary sectors flourished.

Secondly, when employment is broken down into secondary and tertiary sectors the results of the models reveal that, on average, the HSR-based or nearby towns experienced more employment growth in both sectors than elsewhere. In the Employment 2 Model the positive coefficient of HSR station density at the town level $(\mathrm{SDC}=.13)$ suggests that, ceteris paribus, HSR towns on average tended to attract more employment in the secondary sector. Furthermore, in the Employment 3 Model, employment in the tertiary sector is statistically significant in the increased attraction of towns where an HSR station is located within 5 kilometers $\mathrm{ED}(\mathrm{SDC}=.11)$. Taking all of these factors into consideration HSR was among the least influential factors in both models based on their SDCs.

Impacts of HSR station location. This section summarizes the overall findings from the above models regarding the impacts of HSR station location on population and employment redistribution. City-core HSR stations on average attract more population into towns within 5 kilometers ED, as well as into their counties, than the national average, but employment in the secondary sector of towns within 5 kilometers ED declines. Suburban HSR stations on average increase not only population, but also total employment in the towns within 5 kilometers ND or ED. This clustering of employment in or around 
suburban HSR towns may be initiated by both high HSR accessibility for inter-city business trips as well as the ample workspace provided there. HSR stations built in rural areas on average, however, do not have a statistically significant impact on population and employment.

Impacts of HSR shuttle buses. The free HSR shuttle bus service connecting some HSR suburban and rural stations to the nearest city cores is highly correlated with incremental employment in the towns serviced by it but is not correlated with population immigration. Even though the positive coefficients of some HSR shuttle variables are found in the models for individual (SDCs $=.11$ and .25 , respectively) and jointed $(\mathrm{SDC}=.23)$ employment in secondary and tertiary sectors (Table 4), it is unreliable to say that the shuttle service increased employment rather than the contrary: that the routes were designed to service the town's incremental jobs in specific areas. This explanation is supported by the numerous additions and revisions to the routes that have taken place for the 2006 to 2011 evaluation period.

The following analysis of the impacts of non-HSR-related variables helps explain why towns or counties may have experienced population or employment changes not driven by HSR transformation.

Impacts of urban hierarchy, economic size, and economic structure. The findings from the population and employment models show that the impacts of an urban hierarchy and economic size are not statistically significant in affecting a town or county's population or employment during THSR's initial operation period, but they do show that high localizations of some sub-sectors in a town are statistically significant in affecting its employment. Of all the alternate variable forms (e.g., the continuous variable or quartile) under the urban hierarchy (e.g., population size) and economic size (e.g., employment size), none are statistically significant. This finding indicates that no specific type of county caused population or employment change during the evaluation period. Only the dummy variables for two cities, Hsinchu City and Keelung City, are significant which, however, does not imply any distinct impact patterns. In contrast to the overall urban characteristics a high concentration (COL, LQ) of some sub-sectors in a town significantly affected individual and joint employment in the secondary and tertiary sectors, including pharmaceuticals manufacturing $(\mathrm{SDC}=.23)$, high-tech products manufacturing, and travel booking services $(\mathrm{SDC}=.16)$. Additionally, the interaction of the urban hierarchy and economic background variables with the HSR-related variables have been examined in the models to evaluate if they reinforce the impacts on population or employment, but none were found to be significant.

Impacts of other transportation systems. Concerning the control of other transportation's effects when assessing HSR's impacts, the models reveal that the denser an MRT's line coverage (mostly referring to city cores) the lower the population growth $(\mathrm{SDC}=-.65)$. This may be due to a high level of MRT service with high coverage allowing for a more decentralized residential network. Interestingly enough, an MRT's line coverage, with the first line opening in 1996 in Taipei, was the most influential factor for triggering population migration during the evaluation period. Similarly, the more accessible the conventional inter-city rail service the lower the population density of a town became (SDC = -.44). This phenomenon was another highly influential driving force not only affecting population migration but also the net change of employment in the secondary and tertiary sectors. This is possibly due to city core areas, often the oldest parts of the city, experiencing a cycle of decline during the evaluation period.

Regarding the employment models the findings indicate that MRT did not cause a countywide employment boom but instead concentrated employment in MRT-serviced towns as suggested by the positive coefficients of MRT-related variables. Finally, towns with a higher density of highway accessibility attracted more employment in the tertiary sector $(\mathrm{SDC}=.18)$ and joint employment with the secondary sector $(\mathrm{SDC}=.10)$. 


\section{$7 \quad$ Discussion of research findings}

The findings first reveal that, ceteris paribus, the impact of HSR lies at both the sub-city and city levels. On one hand THSR attracts population and employment in the secondary or tertiary sectors to the HSR-based towns or nearby towns on average four years into the operations. This supports the theory that population growth or employment that benefits from HSR may locate or relocate within a certain proximity of HSR stations (Shen et al., 2014), a theory previously absent sufficient evidence or robust methodology. This lack of supporting documentation also casts doubt on the causality between HSR and aggregate territorial transformation of population and employment (Murakami \& Cervero, 2012). On the other hand, the county-level analysis interestingly reveals that HSR-based counties experience less than the national average growth of employment in the tertiary sector, akin to the flourishing of non-HSR counties' tertiary sectors found in the Yangtze River Delta region in China (Li et al., 2016) and Japan (Wetwitoo \& Kato, 2017).

Finally, when the placement of HSR stations is taken into consideration, (a lesser studied factor), the findings show that stations located in urban or suburban settings may cause a more significant impact on average in attracting population to the HSR-based town than elsewhere. This study also reveals that HSR stations built in the city core may increase the associated county's population when compared to instances where the station is built elsewhere. However, when a station is built in the urban core decreased employment in the secondary sector of the city core could occur alongside increased population which may imply a trade-off between the secondary sector and population. These findings on the HSR station placement are consistent with, but more nuanced than, the current understanding that an HSR station in the urban core will most likely stimulate land-use growth (Facchinetti-Mannone, 2006).

This study also aimed to account for the change in population or employment caused not by HSR alone but also by the socioeconomic and transportation characteristics involved in the studied area. The results show that overall urban hierarchy and economic size were not statistically significant in affecting a town or county's population or employment, but that a high concentration of some sub-sectors in a town (such as pharmaceuticals manufacturing, high-tech products manufacturing, and travel booking services) affected employment concentration. Additionally, HSR shuttle buses, MRTs, conventional rail services, and highway accessibility also contributed to this change.

\section{$8 \quad$ Conclusions and policy implications}

This study aimed to expand the current knowledge on the inconsistent spatial impacts of HSR by assessing the average impacts of all eight HSR stations in Taiwan located across multiple metropolitan or urban areas, controlling for socioeconomic and transportation characteristics. The findings support that HSR-based towns or nearby towns tend to experience growing population and employment. HSRbased counties, however, are likely to experience less than national average growth in the tertiary sector. This is potentially due to the prosperity of nearby non-HSR-based counties which benefit from HSR due to their proximity and connecting transportation services. Regarding the placement of stations, those located in urban or suburban settings on average may have a more significant impact on the population growth of their respective HSR-based towns and counties, but secondary sector employment in the city core where the HSR station itself resides tends to decline as a trade-off. The differential between areas at various levels may be attributed to high concentrations of specific sub-sectors and other nonHSR transportation services.

The following policy implications were developed based on the study's findings. Firstly, in the realms of national and regional spatial planning HSR has the potential to be used as a planning tool to encourage economic activity within counties containing an HSR service-shed previously hindered by 
low inter-city accessibility. This is because counties surrounding HSR-based counties may gain relative prosperity in the tertiary sector as a result of higher overall inter-city accessibility. Secondly, as HSR may increase the concentration of population and spur employment growth in HSR-based and other nearby towns, it is recommended that local plans adopt land-use and housing policies that will allow for higher density such as transit-oriented development and urban regeneration. Policies that promote density not only cope with market needs and make use of the economic benefits that HSR service provides, but also allow cities the chance to materialize the concept of the compact city in the HSR-based town and support a future sustainable urban form.

Regarding the strategic placement of HSR stations to promote economic opportunities the research suggests that the short-term impacts of this particular function of HSR services may have the least effect in rural areas. These are therefore suggested as the last choice for station placement, and attempting to initiate new towns by placing HSR stations in rural locales could be risky due to the high costs of establishing infrastructure and services. When selecting the city core for new stations, the respective HSR-based towns are likely to enter a phase suited for the promoting of urban brownfield regeneration as employment in the secondary sector may diminish while the tertiary sector may prosper and population may increase. To take full advantage of the concentration effect of HSR stations, it is recommended to embrace the installation of stations in the suburbs as they have the benefit of being both close to the city core while also boasting ample land for future development.

Research findings from this study are limited by the relatively short-term impact that changes in population and employment have. Furthermore, this before-and-after study conservatively focuses on the impacts of the HSR operation alone without evaluating the potential anticipated impacts of the very announcement of the Taiwan HSR plan, and of the HSR construction itself. This study failed to address the potential endogeneity issue regarding the non-random placement of the HSR station, by, for example, incorporating an instrumental variable (IV) (Diao, 2018), primarily due to the challenge of finding an suitable one for the study. The findings were also drawn from a linear HSR network rather than a spoke-hub or mesh-like layout, which may change resulting impact patterns. Finally, this empirical study is conducted over a relatively small geographic area meaning that inter-city accessibility of most areas has been elevated by HSR to a certain degree and comparative analysis between regions with and entirely without HSR service is limited.

\section{Acknowledgements}

We are grateful to the assistance provided by Elijah Ness. This paper also benefited from the comments and recommendations of two anonymous reviewers.

\section{Funding}

Ministry of Science and Technology, Taiwan Government. MOST 103-2410-H-004 -179 -MY3. 


\section{References}

Bellet, C. (2009). The introduction of the high-speed rail and urban restructuring: The case of Spain. City Futures, 9, 4-6.

Bertolini, L. (1996). Nodes and places: Complexities of railway station redevelopment. European Planning Studies, 4, 331-345.

Blum, U., Haynes, K. E., \& Karlsson, C. (1997). Introduction to the special issue, the regional and urban effects of high-speed trains. The Annals of Regional Science, 31,1-20.

Bruinsma, F. R., \& Rietveld, P. (1998). The accessibility of European cities: Theoretical framework and comparison of approaches. Environment and Planning A, 30, 499-521.

Bryk, S. W., \& Raudenbush, A. S. (2002). Hierarchical linear models: applications and data analysis methods. Thousand Oaks, CA: SAGE Publications.

Cao, J., Liu, X. C., Wang, Y., \& Li, Q. (2013). Accessibility impacts of China's high-speed rail network. Journal of Transport Geography, 28, 12-21.

Chen, C. L., Loukaitou-Sideris, A., Ureña, J. M., \& Vickerman, R. (2019). Spatial short and long-term implications and planning challenges of high-speed rail: A literature review framework for the special issue. European Planning Studies, 27(3), 415-433.

Chen, C. L., \& Hall, P. (2011). The impacts of high-speed trains on British economic geography: A study of the UK's InterCity 125/225 and its effects. Journal of Transport Geography, 19, 689-704.

Chen, G., \& Silva, J. D. (2014). Estimating the provincial economic impacts of high-speed rail in Spain: An application 42 of structural equation modelling. Procedia - Social and Behavioral Sciences, 111, $157-165$.

Diao, M. (2018). Does growth follow the rail? The potential impact of high-speed rail on the economic geography of China. Transportation Research Part A: Policy and Practice, 113, 279-290.

Diya, L., Li., B., Van den Heede, K., Sermeus, W., \& Lesaffre, E. (2014). Multilevel factor analytic models for assessing the relationship between nurse-reported adverse events and patient safety. Journal of the Royal Statistical Society: Series A (Statistics in Society), 177(1), 237-257.

Ewing, R. (2005). Turning highways into main streets: Two innovations in planning methodology. Journal of the American Planning Association, 71, 269-282.

Ewing, R., Schmid, T., Killingsworth, R., Zlot, A., \& Raubenbush, S. (2003). Relationship between urban sprawl and physical activity, obesity, and morbidity. American Journal of Health Promotion, 18(1), 47-57.

Facchinetti-Mannone, V. (2006). Gares ex-urbanisées et développement urbain: Le cas des gares TGV bourguignonnes. Revue de Géographie de l'Est T, XLVI(1-2),15-23.

Facchinetti-Mannone, V. (2009). Location of high-speed rail stations in French medium-size cities and their mobility and territorial implications. Paper presented at the City Futures 2009 Congress, Madrid.

Freeman, A. (2007). London's creative sector: 2007 update (Working Paper 22). London: GLA Economics.

Garmendia, M., Ureña, J. M., Ribalaygua, C., Leal, J., \& Coronado, J. M. (2008). Urban residential development in isolated small cities that are partially integrated in metropolitan areas by high speed train. European Urban and Regional Studies, 15(3), 249-264.

Garmendia, M., Ureña, J. M., \& Coronado, J. M. (2009). High-speed rail, a new mode of suburban metropolitan transport. In Urban transport $X V$-Urban transport and the environment book series: WIT transactions on the built environment (pp. 265-274). Southampton, UK: WIT Press.

Garmendia, M., Ureńa, J. M., \& Coronado, J. M. (2011). Long-distance trips in a sparsely populated region: The impact of high-speed infrastructures. Journal of Transport Geography, 19, 537-551. 
Giuliano, G., Gordon, P., Pan, Q., \& Park, J. (2010). Accessibility and residential land values: Some tests with new measures. Urban Studies, 47(14), 3103-3130.

Givoni, M. (2006). The development and impact of the modern high-speed train. Transport Reviews, 26(5), 593-612.

Gutiérrez, J., González, R., \& Gomez, G. (1996). The European high-speed train network: Predicted effects on accessibility patterns. Journal of Transport Geography, 4(4), 227-238.

Hall, P. (2009). Magic carpets and seamless webs: Opportunities and constraints for high-speed trains in Europe. Built Environment, 35(1), 59-69.

Hayes, A. F. (2006). A primer on multilevel modeling. Human Communication Research, 32(4), 385410.

Haynes, K. E. (1997). Labor markets and regional transportation improvements: The case of high-speed trains, an introduction and review. The Annals of Regional Science, 31(1), 57-76.

Isard, W. (1960). Industrial location analysis and related measures (Chapter 7), in Methods of regional analysis: An introduction to regional science (pp. 252-258). Cambridge, MA: MIT Press.

Kasarda, J. D. (2009). Airport cities. Urban Land, 68(4), 56-60.

Kim, K. S. (2000). High-speed rail developments and spatial restructuring. Cities, 17(4), 251-262.

Kim, H., Sultana, S., \& Weber, J. (2018). A geographic assessment of the economic development impact of Korean high-speed rail stations. Transport Policy, 66, 127-137.

Kreft, I., \& Leeuw, J. D. (1998). Introducing multilevel modelling. London: SAGE.

Levinson, D. (2010). Economic development impacts of high-speed rail (Working paper). Minneapolis, MN: University of Minnesota, Department of Civil Engineering.

Li, X., Huang, B., Li, R., \& Zhang, Y. (2016). Exploring the impact of high-speed railways on the spatial redistribution of economic activities - Yangtze River Delta urban agglomeration as a case study. Journal of Transport Geography, 57, 194-206.

Mohino, I., Delaplace, M., \& Ureña, J. M. (2019). The influence of metropolitan integration and type of HSR connections on developments around stations. The case of cities within one hour from Madrid and Paris. International Planning Studies, 24(2), 156-179.

Mohino, I., Loukaitou-Sideris, A., \& Ureña, J. M. (2014). Impacts of high-speed rail on metropolitan integration: An examination of London, Madrid and Paris. International Planning Studies, 19, 306-334.

Murakami, J., \& Cervero, R. (2012). High-speed rail and economic development: Business agglomerations and policy implications. Berkeley, University of California: UCTC.

Nezlek, J. B. (2012). Multilevel modeling for psychologists (Data analysis and research publication, 219-241). In H. Cooper, P. M. Camic, D. L. Long, A. T. Panter, D. Rindskopf, \& K. J. Sher (Eds), APA handbooks in psychology. APA handbook of research methods in psychology, Vol. 3. Worcester, MA: American Psychological Association.

Norman, C., \& Vickerman, R. (1999). Local and regional implications of trans-European transport networks: The channel tunnel rail link. Environment and Planning A, 31, 705-718.

Pan, Q. (2019). The impacts of light rail on residential property values in a nonzoning city: A new test on the Houston METRORail transit line. Journal of Transport and Land Use, 12(1), 241-264.

Paterson, L. (1991). An introduction to multilevel modelling. In S. W. Raudenbush \& J. D. Williams (Eds), Schools, classrooms, and pupils (pp 85-99). San Diego, CA: Academic Press.

Pedro, M. J. G., \& Silva, J. D. (2013). A contextual analysis of the impacts of high-speed rail on regional development and mobility. Paper presented at the World Conference on Transport Research 2013, Rio de Janeiro, Brazil.

Plassard, F. (1991). Le train à grande vitesse et le réseau des villes. Transports, 345,14-23. 
Preston, J., \& G. Wall. (2008). The ex-ante and ex-post economic and social impacts of the introduction of high-speed trains in South East England. Planning Practice and Research, 23(3), 403-422.

Repolho, H. M., Antunes, A. P., \& Church, R. L. (2012). Optimal location of railway stations: The Lisbon-Porto high-speed rail line. Transportation Science, 47(3), 330-343.

Rouwendal, J., \& Rietveld, P. (1994). Changes in commuting distances of Dutch households. Urban Studies, 31(9), 1545-1557.

Shen, Y., Silva, J. D., \& Martínez, L. M. (2014). HSR station location choice and its local land use impacts on small cities: A case study of Aveiro, Portugal. Procedia-Social and Behavioral Sciences, $111,470-479$.

Taiwan Government. (2015a). National industry and commerce surveys. Retrieved from http://www. dgbas.gov.tw/np.asp?ctNode=2833.

Taiwan Government. (2015b). Census database. Retrieved from http://www.stat.gov.tw/ct.asp?xItem $=15410 \& \mathrm{CtNode}=3624 \& \mathrm{mp}=4 \mathrm{http}: / \mathrm{www} \cdot$ stat.gov.tw $/ \mathrm{ct} \cdot \mathrm{asp} ? \mathrm{xItem}=15410 \& \mathrm{CtNode}=3624 \&$ $\mathrm{mp}=4$.

Taiwan Government. (2018). Transportation database. Retrieved from http://stat.motc.gov.tw/mocdb/ stmain.jsp?sys=100.

Tsai, Y. H. (2001). Travel efficient urban form: A nationwide study of small metropolitan areas (Ph.D. dissertation). Ann Arbor, MI: University of Michigan.

Troin, J. F. (1995). Rail et Aménagement du Territoire. Des Héritages aux Nouveaux Defies. Paris: Edisud.

Ureña, J. M., Menerault, P., \& Garmendia, M. (2009). The high-speed rail challenge for big intermediate cities: A national, regional, and local perspective. Cities, 26, 266-279.

Wang, B., Tsai, Y. H., Chung, Y. H., \& Guan, J. Y. (2020). Spatial patterns of HSR trips (Unpublished paper).

Wetwitoo, J., \& Kato, H. (2017). High-speed rail and regional economic productivity through agglomeration and network externality: A case study of inter-regional transportation in Japan. Case Studies on Transport Policy, 5(4), 549-559.

Willigers, J., \& van Wee, B. (2011). High-speed rail and office location choices. A stated choice experiment for the Netherlands. Journal of Transport Geography, 19(4), 745-754.

Woltman, H., Feldstain, A., MacKay, J. C., \& Rocchi, M. (2012). An introduction to hierarchical linear modeling. Tutorials in Quantitative Methods for Psychology, 8(1), 52-69.

Wu, W., Liang, Y., \& Wu, D. (2016). Evaluating the impact of China's rail network expansions on local accessibility: A market potential approach. Sustainability, 8, 512.

Yin, M., Bertolini, L., \& Duan, J. (2015). The effects of the high-speed railway on urban development: International experience and potential implications for China. Progress in Planning, 98,1-52.

Zhao, Q., \& Chen, G. W. (2015). Impact of location on land-use development around high-speed railway Station. Urban Transport of China, 13, 17-23.

Zheng, S., \& Kahnb, M. E. (2013). China's bullet trains facilitate market integration and mitigate the cost of megacity growth. Proceedings of the National Academy of Sciences of the United States of America, 110(14), E1248-E1253. 